\title{
Protection Model of Workers' Social Security for Participants of Non-Wage Recipients in Semarang
}

\author{
Tri Sulistiyono \\ Faculty of Law, Universitas Negeri Semarang (UNNES), Indonesia \\ Email: trisulistiyono@mail.unnes.ac.id
}

\begin{abstract}
Social security is extremely necessary for every citizen as stipulated in article 28 H paragraph (3) of the 1945 Constitution, particularly for informal workers of non-wage recipients (BPU) in small scale, because there will be no employers responsible for financially helping just in case accidents occur. Data from Social Security Agency (BPJS) on February of 2017 showed that there were 72.67 million $(58.35 \%)$ informal workers and 51.87 million $(\mathbf{4 1 . 6 5 \% )}$ ) formal workers. Based on the data, informal sectors play important roles in providing employment and reducing unemployment. Workers of non-wage recipients in fact take major parts in informal sectors. This study tries to investigate worker regulations controlling social security for workers; then observe the condition of workers of non-wage recipients in Semarang regarding the model of worker social security; and analyze the model of worker social security for workers of non-wage recipients. This sociological juridical study obtained the data through literary studies, documentation, and interview with some parties involving informal workers of non-wage recipients, staffs of Manpower and Transmigration Department (Disnakertrans), and staffs of Worker Social Security Agency (BPJS) in Semarang. The results of this study showed that worker regulations controlling social security for workers have been stipulated in 1945 Constitution; Law number 40 of 2004 on National Social Security System; Law number 24 of 2011 on Social Security Agency (BPJS) and its subsequent regulations. Workers of non-wage recipients still show inadequate condition. Data from Worker Social Security Agency in 2017 indicated that there were $34.000(3.7 \%)$ participants of non-wage recipients and $879.400(96.3 \%)$ participants of wage recipients. The model of worker social security for non-wage recipients is realized through thorough data collection; direct or media-based socialization; coordination across agencies in different sectors; and dues assistance. Insignificant number of the participants of worker social security indicates that inter-sectoral and inter-agencies coordination is required in order to carry out intense socialization, suggesting the importance of registering as the participants of worker social security for non-wage recipients through direct registration in the agency located in the workers' residence. Protection and assistance from the government are also needed in terms of registration and dues for non-wage recipients with low economic abilities.
\end{abstract}

Keywords—Protection Model; worker's social security; non-wage recipient

\section{INTRODUCTION}

Social security is extremely necessary for every citizen as stipulated in article $28 \mathrm{H}$ paragraph (3) of the 1945 Constitution stating that everyone deserves social security that enables his/her complete development as a dignified human being, particularly for workers of non-wage recipients and their family as there are no employers responsible for financially helping just in case accidents occur. In addition to the provision stated in the 1945 Constitution about workers, the government has also issued worker regulations such as Law No.13 of 2003 on employment, Law no. 21 of 2000 on Trade Unions, Law no. 4 of 2004 on national social security, and so on. However, with respect to the existence of various laws and regulations, there are still many workers in informal sectors who receive lack of attention and protection.

The existence and sustainability of informalsector activities in economic system as the reality of democratic economy plays an important role in the development of society and nation. At least, when development programs are less likely to provide job opportunities for workforce, the informal sectors with all of their pitfalls can serve as place to accommodate and alternative job opportunities for job seekers. A wave of dissatisfaction of the poor and the unemployed with the incapability of development in providing job opportunities can temporarily be prevented due to the availability of job opportunities in informal sectors. Moreover, with a flood of layoffs as an impact of global financial crisis also affects the sustainability of companies in Indonesia. Data from BPS in February of 2017 showed that informal there were 72.67 million $(58.35 \%)$ million workers and 51.87 million $(41.64 \%)$ formal workers. Based on the data, informal sectors hold important role in absorbing employment and reducing unemployment. Non-wage recipient workers take big part of in informal sectors. The data shows that informal sectors are still dominant enough in absorbing workforce, especially in urban areas. Informal workers may consist of non-wage recipient and wagerecipient workers

Legislation at this moment in time rarely deals with the protection of informal workers, including nonwage workers. Legal norms of worker protection have been largely regulating work relationship for formal workers. It also needs to bear in mind that informal sectors become a valve of social safety and contribute enormously to job availability. The government should accordingly attempt to protect informal workers, including non-wage recipients optimally. The attempt needs to be applied to 
both legislation level and its implementation in the community.

Non-wage recipient workers in informal sectors are very vulnerable to risks such as illness and work accidents as they generally work in less organized-way or frequently ignore safety regulation. Besides, non-wage recipient workers who come from middle-class economy tend to think about their daily needs.

\section{RESEARCH METHOD}

Research Approach and Type: The study used qualitative method and was included as juridical empirical research. The data of this juridical empirical research was taken from primary data in which it was obtained through interviews and observations. In addition to the primary data, this empirical juridical research was also supported by secondary data obtained through literature study in order to set the theoretical basis such as opinions, experts' writings, and data obtained from available official manuscripts. This study concerned on searching and inventorying data such as worker regulations controlling protection of workers' social security; how the condition of non-wage recipient workers within workers' social security in Semarang is; and how the protection model of workers' social security for non-wage recipients in Semarang is.

Subject and Location of the Study: This study aimed at revealing the protection model of workers' social security for non-wage recipients in Semarang. Thus, this study involved informal workers of non-wage recipients in Semarang as the subject of the study. This study took place in the Regional Office of Manpower and Transmigration Department (Disnakertrans) and Workers Social Security Agency (BPJS Ketenagakerjaan) in Semarang.

Methods of Collecting the Data: In collecting the data, the researcher used several techniques as follows: (1) Literature Study; The literature study was used to search for worker regulations, concepts, theories, opinions, or findings related to the protection of worker' social security for non-wage recipients, (2) Interviews; This study used structured interviews, in which the questions was based on the list of questions made as the interview guideline, but improvement was still possible. Thus, naturalness could be still achieved to obtain in-depth data with regard to the possible variations of questions adjusted to the situations and conditions when the interviews were conducted. The goals of conducting interviews were to obtain detailed and in-depth information about respondents' perspective and particular event, situation and circumstance. Interviews were conducted with several informal workers including non-wage recipients, as well as officers from the Regional Office of Manpower and Transmigration Department (Disnakertrans) and Workers Social Security Agency (BPJS Ketenagakerjaan) in Semarang, (3) Documentation; Document is a record of past events. Documents may be in the forms of writing, drawing or monumental work of a person. This documentation technique was carried out to search for and collect the data related to this study. Compared to the other data collection methods, this method is considered less difficult as in case errors occur, the data remains the same. Documentation was carried out by collecting data through written relics such as archives and books containing constructs, theories, propositions or laws and other things related to the research problems. The data in this study was collected by investigating documents related to membership of Workers Social Security Agency (BPJS Ketenagakerjaan) for non-wage recipients in Semarang.

\section{RESULT AND DISCUSSION}

\section{A. Worker Regulations Controlling Prosperity Protection for Workers}

Informal workers of non-wage recipients become an important factor in generating economy in a country despite facing monetary crisis. Therefore, there is a need to protect them for the sake of their sustainability. The government has made several regulations aimed at regulating the protection of informal workers of non-wage recipients. Worker regulations that control prosperity protection for informal workers of non-wage recipients can be seen in:

1. The 1945 Constitution

In the fourth paragraph of the preamble of the 1945 Constitution, it is explicitly stated the second national goal is to advance general prosperity. It implies that the prosperity belongs to all Indonesians, including prosperity for informal workers of non-wage recipients who need to be protected regarding the goal of establishing the Unitary State of the Republic of Indonesia. Furthermore, the articles of the 1945 Constitution also contain protection for workers. Article 27 paragraph (2) of the 1945 Constitution states that every citizen deserves good work and life for the sake of humanity; Article 28 A of the 1945 Constitution contends that everyone has the right to live and sustain his/her life. Article 28 D of the 1945 Constitution affirms that everyone has the right to work and deserves rewards and fair treatment in the employment. Article 28 E (1) of the 1945 Constitution states that everyone can freely belong to any religion and worship according to his/her religion, choose education, teaching, job, citizenship, take up a place of residence, leave it, and return. Provisions stated in the 1945 Constitution become the principles for the government to establish the subsequent technical regulations.

2. Law No. 13 of 2013 on workers

In the general provisions of Law No.13 of 2003, it is affirmed that workers are those who is capable of doing works to produce goods and/or services to meet their needs or the community's. The article above explains that the definition of workers according to this law embraces non-employed and employed workers using their strength as the production tools, including both physical and mind tools. The definition is in line with the definition of worker based on the concept of employment in general - the definition involves those who have worked, who are working, who are looking 
for works, and who are doing other works. Other provisions on prosperity in Law of worker are that:

a) every worker deserves equal treatment without discrimination from their employers.

b) every worker has right to acquire and/or improve and/or develop work competence in accordance with his/her talents, interests and abilities through job training.

c) every worker has right to be protected in terms of his/her:

1. occupational safety and health

2. moral and decency

3. treatments based on human dignity and religious values

d) every worker deserves salary which meets good living.

e) every worker and his/her family deserve workers' social security.

3. The social security for informal workers of non-wage recipients is stipulated in Law No. 24 of 2011 on Social Security Agency (BPJS) and Presidential Decree (Perpres) No.109 of 2013 regarding membership procedures of social security program, and the provisions are explained as follows:

The objectives of workers' social security for informal workers of non-wage recipients are to:

a. provide social security protection for workers included as non-employed workers once they incur partial or complete losses as a result of risks such as work accidents, illness, pregnancy, childbirth, old age, and death.

b. extend the membership scope of workers' social security

Besides, workers' social security gives significance as follows:

1. Work accident insurance (JKK) includes transport costs, costs for medical treatment, rehabilitation, salary due to temporal working inability (STMB), compensation for permanent partial disability and permanent total disability, death compensation (based on the label), funeral costs, and periodic compensation for the deceased as well as permanent total disability.

2. Life insurance (JK) comprises funeral costs and periodic compensation.

3. Old age insurance (JHT) consists of the entire paid-in dues as well as the interests.

Requirements for registering to this program:

a. The participants voluntarily register.

b. The participants' age is less than 55 years-old

c. The participants are willing to continuously follow the rules of workers social security program and to choose the program that suits their needs.

d. The participants are welcomed to directly register to BPJS offices or the available groups.

The amount of LHK TK dues is set based on certain nominal values with regard to the salary at least equivalent to provincial/district/city minimum salary. Different from formal workers whose social security is largely paid by the employers, non-wage or TKLHK recipients is entirely responsible for the dues.

\section{B. Conditions of Workers' Social Security for Non-Wage Recipients in Semarang \\ Informal sectors have greater proportion of workers} of non-wage recipients than formal sectors do. The data is displayed in the following table:

Table 1. Data of formal and informal workers of non-wage recipients

\begin{tabular}{|c|c|c|c|}
\hline No. & Year & Formal Workers & $\begin{array}{c}\text { Informal Workers of } \\
\text { Non-Wage Recipients }\end{array}$ \\
\hline 1 & 2016 & $\begin{array}{c}51.870 .000 \\
(42,45 \%)\end{array}$ & $70.300 .000(57,55 \%)$ \\
\hline 2 & 2017 & $\begin{array}{c}50.210 .000 \\
(41,65 \%)\end{array}$ & $72.670 .000(58,35 \%)$ \\
\hline \multicolumn{3}{|c|}{ Source: Central Statistics Agency (BPS) }
\end{tabular}

Based on the data above, there is a need to give social security protection for informal workers of nonwage recipients, as well. However, it is showed that there is only small proportion of membership of workers' social security for non-wage recipients than that of wage recipients. Based on the data from Workers Social Security Agency (BPJS Ketenagakerjaan) in 2016 - 2017, there were 34.000 workers of non-wage recipients and 879,400 workers of wage recipients registered in workers social security program in Semarang.

The purpose of Law No. 13 of 2003 on workers is stated in article 1 point 31 - that workers' prosperity is a fulfillment of physical and spiritual needs for both nonemployed or employed workers, which can directly or indirectly enhance work productivity in a safe and healthy working environment.

Worker development is aimed at:

a. empowering and employing workers optimally and humanely;

b. realizing equal job opportunities and supply of workers according to the needs of national and regional development;

c. giving protection to workers in realizing prosperity; and

d. improving prosperity for workers and their family.

However, given the real condition of the workers' prosperity, it can be seen various worker regulations have not been able to protect the prosperity of informal workers of non-wage recipients. It can also be seen from low number of informal workers of non-wage recipients protected by social security as displayed in the following table.

Table 2 Membership of BPJS Ketenagakerjaan in 2017

\begin{tabular}{|c|c|c|c|c|}
\hline No & $\begin{array}{c}\text { Total } \\
\text { Membership }\end{array}$ & $\begin{array}{c}\text { Active } \\
\text { Members }\end{array}$ & $\begin{array}{c}\text { Formal } \\
\text { Workers }\end{array}$ & $\begin{array}{c}\text { Informal } \\
\text { Workers }\end{array}$ \\
\hline 1 & 48 millions & 22,6 millions & 21,2 millions & 1,4 millions \\
\hline
\end{tabular}

Source: BPJS

Based on the data above, there were only small numbers of informal workers of non-wage recipients protected by workers social security. Therefore, it needs various attempts to increase the number of informal workers of non-wage recipients protected by social 
security such as work accident insurance, life insurance, and old age insurance.

\section{Protection Model of Workers' Social Security for Non-Wage Recipients in Semarang}

Workers of non-wage recipients (BPU) are those engaged in economic activities independently and working in small-scale economy to earn income, examples of such workers are ojek drivers, public minivan (angkot) drivers, salesmen, doctors, lawyers/advocates, artists, fishermen, etc.

Members of non-wage recipients:

1. are able to take part in PBJS program periodically by choosing the program suitable to their needs.

2. are able to directly register to BPJS Ketenagakerjaan branch offices or groups/partners/payment points (aggregators/banks) in partnership with BPJS Ketenagakerjaan.

There are three programs provided for workers of nonwage recipients as follows - only pension insurance is not included.

1. Work accident insurance (JKK) includes transport costs, costs for medical treatment, rehabilitation, salary due to temporal working inability (STMB), compensation for permanent partial disability and permanent total disability, death compensation (based on the label), funeral costs, and periodic compensation for the deceased as well as permanent total disability.

2. Life insurance (JK) comprises funeral costs and periodic compensation.

3. Old age insurance (JHT) consists of the entire paid-in dues as well as the interests.

Table 3. Dues paid by workers of non-wage recipients for BPJS Ketenagakerjaan programs

\begin{tabular}{|l|l|}
\hline \multicolumn{1}{|c|}{$\begin{array}{c}\text { Programs of BPJS } \\
\text { Ketenagakerjaan }\end{array}$} & \multicolumn{1}{c|}{ Dues } \\
\hline Work Accident Insurance & $\begin{array}{l}1 \% \text { (from certain nominal } \\
\text { number of salary) }\end{array}$ \\
\hline Life Insurance & Rp. 6.800,-- \\
\hline Old Age Insurance & $2 \%$ \\
\hline
\end{tabular}

Socialization is carried out by BPJS Ketenagakerjaan in Semarang through:

a. direct socialization in markets by organizing particular events

b. mass media (print media and radio)

c. related offices (i.e. Marine and Fishery Office for fishermen and Market Office for salesmen)

Registration procedures/requirements:

1. having identity card number (NIK)

2. filling out F1 BPU form for new members

3. contacting the following parties:

a. the closest BPJS Ketenagakerjaan Branch offices

b. related groups

c. Partners/Payment Points (aggregators/banks) in partnership with BPJS Ketenagakerjaan

Dues payment can be made by the participants themselves or groups/partners/payment points/aggregators/banks every month/ three months/ six months/ one year.

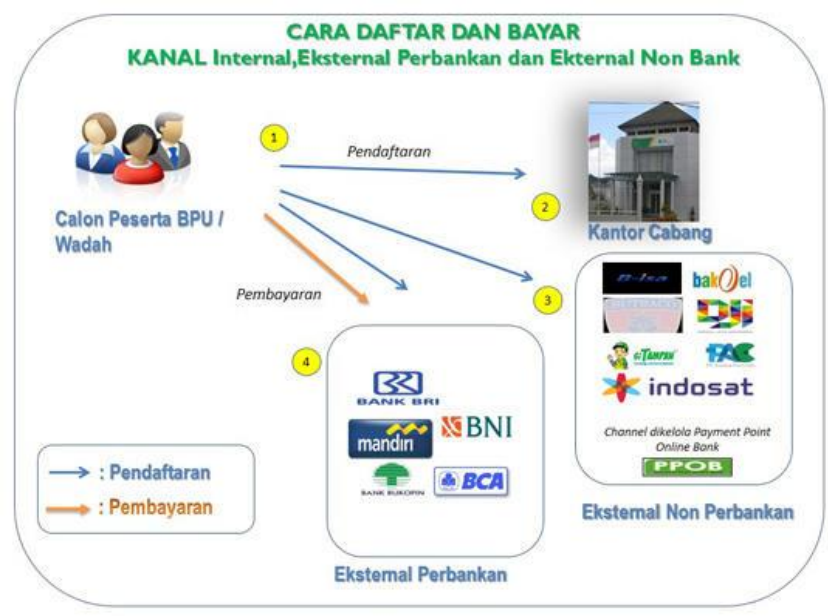

Fig. 1 Registration and payment model of Workers Social Security (BPJS Ketenagakerjaan) for workers of non-wage recipients

Proposing claim for work accident insurance for workers of non-wage recipients requires the same procedures for workers of wage recipients. It is carried out in several steps as follows.

a. If the participant is involved in work accidents, she/he is required to fill out form 3 of BPJS Ketenagakerjaan (first stage of the accident report) and submit it to BPJS Ketenagakerjaan office in $2 \times 24$ hours since the accident. Hence, accident report needs to be immediately made once it occurs.

b. After the worker recovers from the accident or passes away according to medical results from the doctor, the employer needs to fill out form 3 a (second stage of the accident report) and submit it to BPJS Ketenagakerjaan office in $2 \times 24$ hours from the time the worker recovers or passes away. Then, BPJSTK will calculate the cost and pay the compensation to the worker/ the heirs according to the provisions.

c. Form 3a of BPJS Ketenagakerjaan functions as a request for insurance payment by enclosing: copy of membership card (KPJ), statement from the doctor in $3 \mathrm{a}$ or $3 \mathrm{c}$ forms, bills of medical treatment costs as well as transport costs.

Those requirements must be fulfilled to enable claim process of JKK BPJS Ketenagakerjaan. This program helps the members/workers registered in BPJS Ketenagakerjaan to get health service and compensation. 

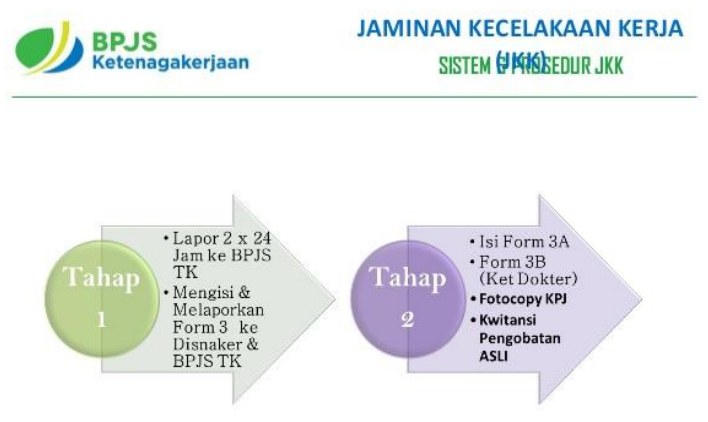

Fig. 2. Procedures of proposing claim of work accidents

Proposing claim for life insurance for workers of non-wage recipients takes the same procedures for workers of wage recipients. It is carried out in several steps as follows. Relatives of the deceased fill out form 4 of BPJS enclosed by the following documents:

1. BPJS Ketenagakerjaan member card of the deceased

2. Death statement issued by hospital/police/the head of urban village

3. Copy of identity card (KTP)/ driving license/ family card of the deceased

4. Identity of the heirs (copy of identity card/ SIM/ family card)

5. Statement issued by the head of urban village about the heirs

6. Stamped power of attorney and copy of the agent's identity card (if the insurance is authorized)

Proposing claim for old-age insurance for workers of non-wage recipients takes the same steps for workers of wage recipients. It is carried out in several steps as follows.

These requirements are enclosed by documents that must be submitted directly to BPJS TK office. Documents needed for proposing old-age insurance (JHT) 10\% and $30 \%$ are:

1) For claiming $10 \%$ balance of old-age insurance:

a. Copy of BPJS TK member card/Jamsostek, enclosed by the authentic one

b. Copy of identity card (KTP) or passport, enclosed by the authentic one

c. Copy of family card (KK), enclosed by the authentic one

d. Saving account book

2) For claiming $30 \%$ balance of old-age insurance:

a. Copy of BPJS TK member card/Jamsostek, enclosed by the authentic one

b. Copy of identity card (KTP) or passport, enclosed by the authentic one

c. Copy of family card (KK), enclosed by the authentic one

d. Residence documents

e. Saving account book

Proposing claims can be carried out by directly coming to the BPJS Ketenagakerjaan office or through on- line system known as e-claims. The available system can be easily accessed, but there is only small membership of PBU. Besides, the main factor of inadequate protection is less intensive socialization on the importance of workers' social security for non-wage recipients

\section{CONCLUSION}

From the results of this study on the model of social security protection for workers of non-wage recipients, it can be drawn some conclusions as follows: (1) worker regulations controlling workers' prosperity protection are stated in fourth paragraph of the preamble of the 1945 Constitution, Article 27 paragraph (2) and Article 28 D. Moreover, they are also stated in Law No. 13 of 2003 on workers. However, there is only a few of them regulating informal workers of non-wage workers although the general the provisions include informal workers of nonwage recipients as workers. Then, social security for informal workers of non-wage recipients is regulated in Act No. 24 of 2011 on Social Security Agency (BPJS) and Presidential Decree (Perpres) No.109 of 2013 regarding the membership procedures of social security program. Then, Social security membership embraces very small proportion of non-wage recipient workers compared to wage-recipient workers. Based on the data from Workers Social Security Agency (BPJS Ketenagakerjaan) in 2016 2017, there were 34.000 workers of non-wage recipients and 879,400 workers of wage recipients registered in workers social security program in Semarang. Social security protection for workers of non-wage recipients can be achieved by several means such as socialization through mass media (including print, electronic, and online media) and direct visit to the workers' location. Registration and payment can be carried out by directly visiting BPJS TK offices, banks, and non-banking online application. Claims can be proposed through direct visit or e-claim

\section{REFERENCES}

[1] Amiruddin. dan Zainal Asikin.2004. Pengantar Metode Penelitian Hukum. Jakarta: Raja Grafindo Persada.

[2] Asyhadie, Zaeni. 2013. Aspek - aspek Hukum Jaminan Sosial Tenaga Kerja di Indoensia. Jakarta: Raja Grafindo Persada.

[3] Burhan Ashofa. 2013. Metode Penelitian Hukum. Jakarta: Rineka Cipta.

[4] Hadikusuma, Hilman. 1995. Metode Pembuatan Kertas Kerja atau Skripsi Ilmu Hukum. Bandung: Mandar Maju.

[5] Husni, Lalu. 2014. Pengantar Hukum Ketenagakerjaan Edisi Revisi. Jakarta: Raja Grafindo Persada.

[6] Khakim, Abdul. 2007. Pengantar Hukum Ketenagakerjaan Indonesia, Bandung:PT Citra Aditya Bakti

[7] Moleoeng, Lexy J. 2013. Metodologi Penelitian Kualitatif. Bandung: PT. Remaja Rosdakarya.

[8] Rahardjo, Satjipto. 2009. Penegakan Hukum: Suatu Tinjauan Sosiologis, Yogyakarta: Genta Publishing. 
[9] Soekanto, Soerjono dan Sri Mamudji. 2001. Penelitian Hukum Normatif (suatu tinjauan singkat). Jakarta: Rajawali Pers.

[10] Subarsono. 2015. Analisis Kebijakan Publik: Konsep, Teori, dan Aplikasi. Yogyakarta: Pustaka Pelajar.

[11] Mohanty, Subhransubala. 2012. Sosial Security in Informal Sector: A Myth. Odisha Review Journal 60-69

[12] Soewartoyo. 2010. Pekerja Sektor Informal: Pemberdayaan dan Peningkatan Kesejahteraan. Laporan Akhir Program Insentif Peneliti dan Perekayasa LIPI.

[13] Sulistiyono, Tri. 2015. Study on the Informal Workers' Welfare in Micro Small Business in Gunungpati District of Semarang. International Journal of Business, Economics, and Law. Volume 6/4: 67-73

[14] Triyono dan Soewartoyo. 2013. Kendala Kepesertaan Program Jaminan Sosial Terhadap Pekerja Di Sektor Informal: Studi Kasus di kota Surabaya. Jurnal Ilmu Hukum volume 3(3).

[15] The 1945 Constitution of the Republic of Indonesia

[16] Law No.4 of 2004 on National Social Security

[17] Law No. 13 of 2003 on Workers. 